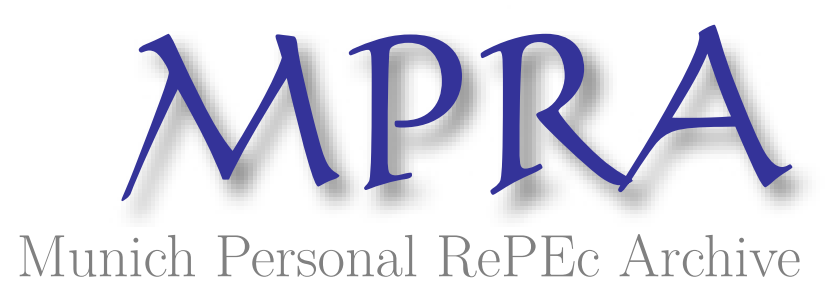

\title{
Health and Christianity: Controlling for Omitted Variable Bias by Using the Data of Twins and Siblings
}

HONG, DING

2 August 2012

Online at https://mpra.ub.uni-muenchen.de/41334/

MPRA Paper No. 41334, posted 19 Sep 2012 11:34 UTC 


\title{
Health and Christianity: Controlling for Omitted Variable Bias by Using the Data of Twins and Siblings
}

\section{Hong Ding ${ }^{1}$}

\begin{abstract}
To account for potential bias from heterogeneity in hereditary factors or family background, I use the within-twin and within-siblings differences to estimate the effects of Christian faith on three health outcome variables by applying fixed effect model to the data of twins and siblings from the first wave of the National Survey of Midlife in the United States (1995). Both this model and other statistical tests and model without controlling for omitted variable bias confirm significant positive health effects of religiosity of Christianity. The results also support the three explanatory mechanisms of religion on health proposed by Son and Wilson (2011): 1) behaviors and lifestyles, 2) social networks and 3) social support and psychological resources. However, the data also suggests that either other channels through which religiosity affects health may exist or the mechanism of psychological resources goes far beyond of "good moods" and contains much more plentiful and profound connotations that is relevant to health.
\end{abstract}

\section{INTRODUCTION}

In recent years, a growing number of rigorous studies have shown that religiosity or spirituality, including prayer, attendance at religious services or just faith of God, benefits health in ways that science hasn't fully explained. Among other effects, regular worship and other spiritual acts appear to lengthen life expectancy, strengthen immunity, improve the body's response to stress, and boost other measures of physical health (Myers (2008:336). As Son and Wilson (2011) summarized, numerous scholarly reviews have

\footnotetext{
${ }^{1}$ E-mail: kevinding66@gmail.com
} 
concluded that religious people enjoy better physical health, including "global selfratings of health; individual items and rating scales assessing functional health and disability limitation; physical symptomatology; the incidence and prevalence of cancer, both overall and site specific; the incidence and prevalence of coronary heart disease, hypertension, and cerebrovascular disease" (Levin and Chatters 2008:160). Oman and Thorenson (2005:454) describe the relation between religion and physical health as "robust." Myers (2008:336) declares that "religious involvement rivals nonsmoking and exercise effects" as a predictor of physical health and longevity.

Despite a large volume of empirical literature holding supportive view on the health impact of religion, this topic has been a debate up to now. Son and Wilson (2011) provides an excellent summary of the literature with suspicion of or criticism against the above claimed health effect of religion. Powell and colleagues discovered that none of three "well-controlled, prospective studies of the elderly . . . found any relationship between the religious variable and the development of disability" (Powell, Shahabi, and Thorenson 2003:43). In a study by Koenig and Vaillant (2009) the positive effect of church attendance on health disappeared over time. Kelly-Moore and Ferraro (2001) detected no effect of religious service attendance on functional limitations. A recent study of respondents in the Wisconsin Longitudinal Study, who were tracked from 1993 (when they were 53-54 years old) until 2004 (when they were 64-65 years old), found no association between either church attendance or religious importance and self-rated health (Brenner and Siegl 2008). Levin and Vandepool (1987) examined 27 previous studies relating religious attendance to health for possible problems and their conclusion is that there is insufficient evidence to conclude that religious attendance is positively and significantly related to health.

The main point in Levin and Vanderpool (1987) and Levin (1994) is that the previous studies claiming to find a positive and significant effect of religion may not be valid because of the following problems:

1) including too few control variables so that seemingly significant association may be biased by confounding; 
2) failing to take into account reverse causality so that it may be because more healthy people go to church more frequently rather than vice versa.

3) The variables chosen to measure health and religion are not appropriate, for example, some studies are actually investigating the relationship between religion and health behaviors rather than health status.

Similar critique was also raised by other researcher that adequate controls for possible moderating or confounding factors that could explain health outcomes have often been missing (Thoresen (1999)).

The impact of religion on health has always been a tricky area of research. It seems (to some) that religious people (defined here as people who go to religious services regularly) seem to do better than those who do not go. This has led to a line of research looking into the impact of religion on health to determine what, if any, positive benefit religion could have on physical and mental health. This research is tricky because of several factors:

- $\quad$ people who attend religious services may simply be healthier than those that cannot attend

- the benefits may have more to do with social contact or social support than religion itself

- $\quad$ certain religions may encourage behaviors that are healthy

Among the three factors mentioned above, first is reverse causality or simultaneity problem, the remaining two points are relevant to omitted variable bias (OVB) that are common for studies based on observational data.

The inconsistency and controversy in previous literature is due to one simple reason: the previous studies did not address omitted variable bias or fully address bias from reverse causality in regressions for observational data regarding religiosity and health. Except some studies on the effect of distant prayer (Thoresen (1999), Harris (1999), Leibovici (2001)), which used randomized double-blind experiments designs, all the studies on health effect of religion are based on observational data, either retrospective or prospective. The root of above-mentioned inconsistency is due to potential confounding existed in non-experimental setting. In statistics term, the coefficient of the key 
explanatory variable of religiosity may be endogenous (thus not consistent) because of confounders (omitted variables) not included in the regression but should be in the model or because of failing to account for mutual causality between dependent variable and independent variables. In other words, the fact that previous studies did not include enough control variables to explain health outcomes in addition to religiosity variable thus omitting some important determinants of health makes omitted variable bias unavoidable for the estimator of religiosity variable. In fact, other studies have shown that people who regularly attend religious services may be more likely to be employed, to have larger social networks, to be more positive, to live in intact families and to not be experiencing disabling illness. Any of these factors could explain the difference in health outcomes observed in those studies on health effect of religion. The direction of the omitted variable bias depends on the estimators as well as the covariance between the regressors and the omitted variables. Given a positive estimator, a positive covariance will lead OLS estimator to overestimate the true value of an estimator.

We can never perfectly eliminate all confounding effects given infeasibility, if not impossibility of implementing a randomized experiment on the effect of some religion measures, say religious service attendance. However, we can use some statistical methodology to alleviate the confounding bias to the greatest extent. This paper is such an attempt.

Isolating omitted variable bias is not only important for getting an unbiased and consistent estimator of religiosity variable, it is closely related to our exploration of the mechanism of the health impact of religiosity. It may be simply that people who attend religious services tend to have more social and financial resources than non-attendees, or it could be that something about attending religious services (like making connections with others, prayer, or spiritual reflection) helps people to have better health. This paper aims to use rigorous statistical evidence to investigate whether we can rule out the first possibility and if so what aspect of religion, particularly Christianity is more relevant to improving health.

In addition, if an observational study does not include a variable proxying previous health status then it may also suffer from endogeneity bias arising from reverse causality. The 
observed effect of frequency of attending religious services on health may only be because healthier people go to services more often.

\section{DATA}

I use the data from the National Survey of Midlife Development in the United States (MIDUS). MIDUS is a collaborative, interdisciplinary investigation of patterns, predictors, and consequences of midlife development in the areas of physical health, psychological well-being, and social responsibility. This is a survey of a nationally representative sample of 3,487 English-speaking noninstitutionalized adult Americans aged 25 to 74 (birth cohorts from 1920 to 1970). Respondents were recruited through the random-digital-dialing (RDD) samples of working telephone accounts. The baseline national RDD sample was selected in 1995 from working telephone banks. Males between ages of 65 and 74 were oversampled. The respondents participated in a computer-assisted telephone interview and also completed two self-administered questionnaire booklets mailed to their households. The response rate estimates are 70 percent for the telephone interview, 86.8 percent for the completion of the selfadministered questionnaires, and 60.8 percent for the combined response (i.e., .700 $\times$ $.868)$.

The sample was comprised of individuals from four subsamples: (1) a national RDD (random digit dialing) sample $(\mathrm{n}=3,487)$; (2) oversamples from five metropolitan areas in the U.S. ( $\mathrm{n}=757)$; (3) siblings of individuals from the RDD sample ( $\mathrm{n}=950)$; and (4) a national RDD sample of twin pairs $(n=1,914)$. The last two subsamples of twins and siblings provide us with an opportunity to control for omitted variables as explained in the next section.

For this dataset, $74.7 \%$ of the respondents choose Christianity (either protestant, Catholic or Orthodox) when asked the question 'What is your religious preference?', only 4.21\% choose other religions (Jewish, Buddhist, Hindu, Muslim, Rastafarian and Other). Because I have removed all the respondents whose religious preference is any one of the above-mentioned non-Christianity religions, the study dataset includes only Christians 
and agnostic or atheist and people with no religious preference. So this paper is essentially studying the health effect of Christianity.

One of the two major health outcome variables used in this paper is self-rated score of either physical or mental health status. Self-rated health asks respondents to give an overall assessment of their current physical or mental health, ranging from poor to excellent. Asking respondents to give an overall assessment of their health is a widely used measure of health status and is considered to be an accurate measure of a person's physical/mental health status (Bjorner, Fayers, and Idler 2005:314). The measure is predictive of chronic disease incidence, recovery from illness, and functional decline (Idler and Kasl 1995:S35; Shields and Shooshtari 2001:37).

Another health outcome variable is never used in previous literature. It is the number of days within a month when respondent cannot work or carry out normal household work activities because of physical health or mental health problem, a measure of negative health outcome. Since this number is not normally distributed, standard Analysis of Variance (ANOVA) cannot be applied to this response variable when other control variables are included.

The variable definition and values taken by each variable used in this paper are presented in table 1, the descriptive statistic of these variables are shown in table2.

\section{GRAPHICAL INVESTIGATION OF RELIGIOSITY EFFECTS}

Illustrated in Figure 1 is the mean response of physical health score by frequency of religious attendance. As shown there, people attending church services about once a week have the best performance (mean response $=3.71$ ). People never goes to church have the worst health outcome (mean response $=3.46$ ). Note there is a substantial difference in response between those going to church sometimes to those never going. Thus, there appears to be empirical evidence of a religiosity treatment effect. However, the relationship between religious involvement and health status is not linear. 
Figure 1

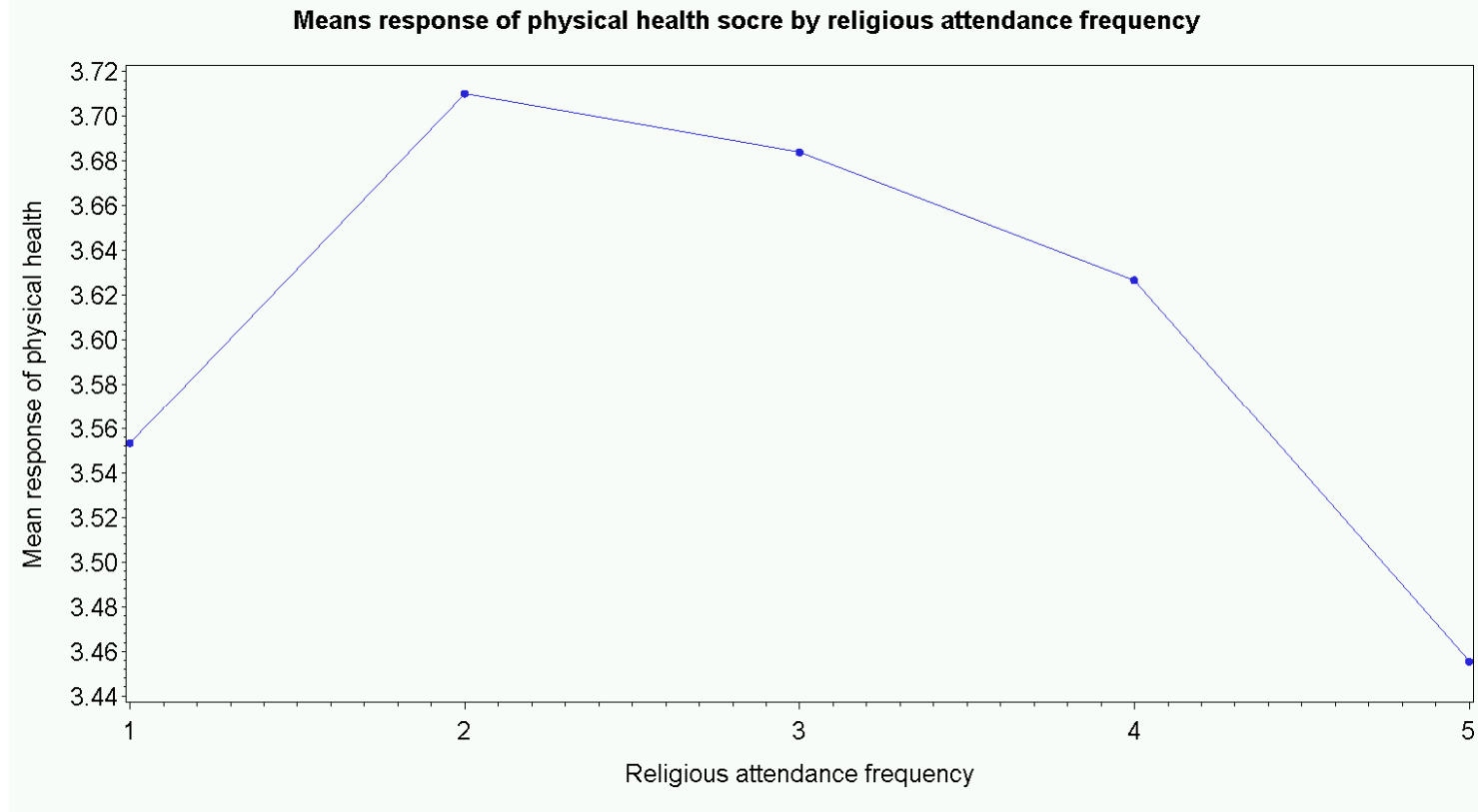

$1=$ more than once a week, $2=$ about once a week, $3=$ one to three times a month, $4=$ less than once a month, $5=$ never

The figure 2 showing similar relationship between mean response of mental health score and religious attendance gives similar result. Now the relationship becomes nearly linear.

Figure 2

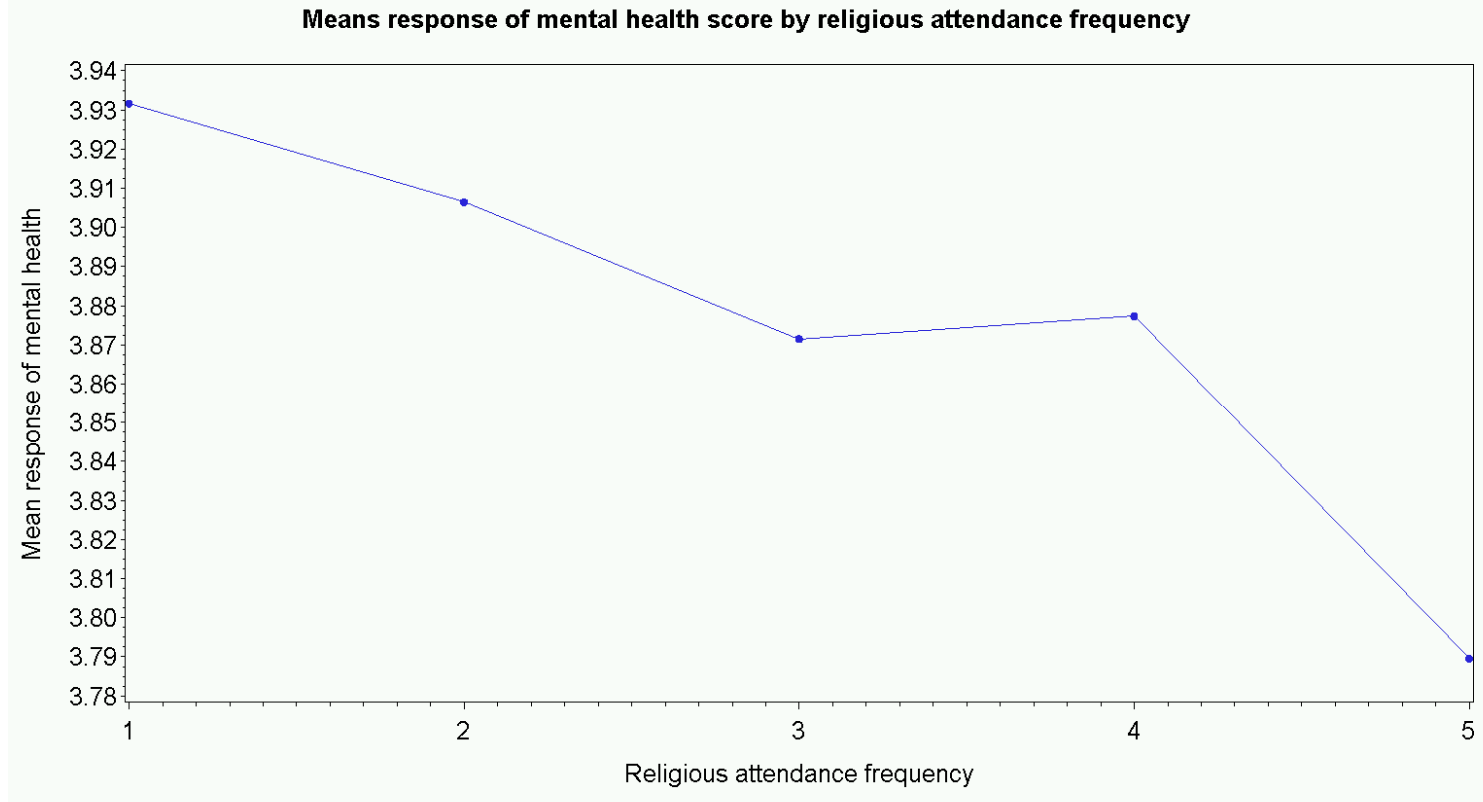

$1=$ more than once a week, $2=$ about once a week, $3=$ one to three times a month, $4=$ less than once a month, $5=$ never 
I also investigate whether religious attendance frequency has positive effect on the number of days off work due to health by this graph means. It is very clear from figure 3 that nonattendees have much higher average number of days off work due to health than attendees. Specifically, the mean response for frequency $=2$ is 0.62 while that for frequency $=5$ is 1.23 .

\section{Figure 3}

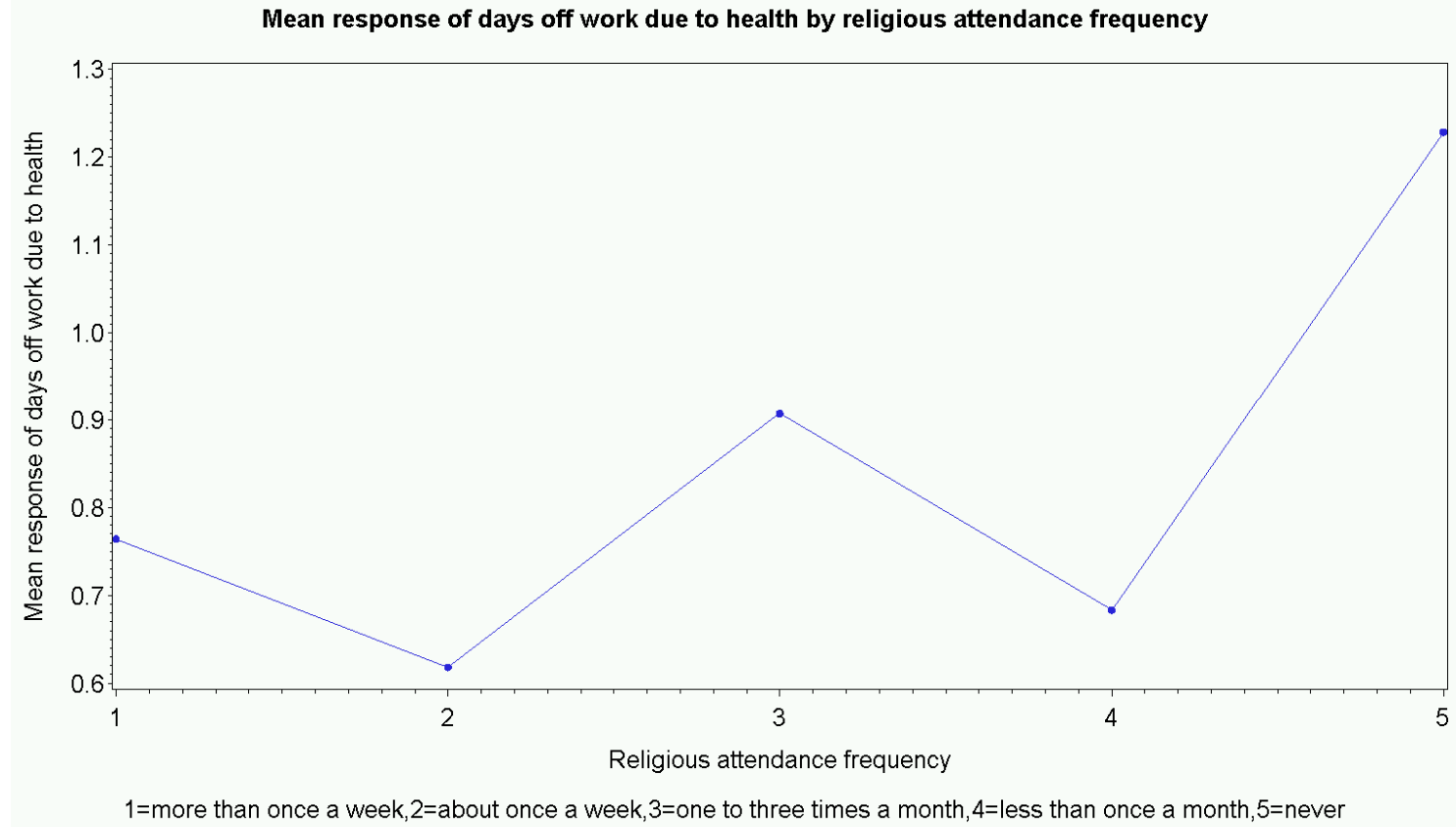

\section{STATISTICAL TESTS AND MODEL WITHOUT CONTROLLING FOR OVB}

\subsection{Correlation: Testing for the Strength of Ordinal (Ranked) Relationships}

I use two correlation coefficients to test the strength of association between health outcome variables and religiosity variables, both of which are measured at the ordinal level: Spearman's rho $(\rho)$ and Kendall's rank order correlation coefficient or Kendall's tau $(\tau)$. Both Spearman's rho and Kendall's tau require that the two variables, $\mathrm{X}$ and $\mathrm{Y}$, are paired observations, with the variables measured are at least at the ordinal level. Like the parametric Pearson product-moment correlation coefficient, both these measures can range between -1.0 and +1.0 , with a positive correlation indicating that the ranks increase together, while a 
negative correlation indicates that as the rank of one variable increases the other one decreases.

The table 4 shows that both Kendall Tau and Spearman correlation coefficients for variables health and attend are negative and significant for twin data at 5\% level, indicating that as the rank of attend increases, the health status index decreases. Referring to table 1, we know that it means a decrease in religious attendance frequency will lead to a worsening of health status. The negative association also exists between health_m and attend, between health_m and ident_relig for sibling data at $1 \%$ significance level, the latter of which suggests that less extent of identification with religious group is always associated with worse mental health status. A similar but weaker relationship is also found for twin data (at $10 \%$ significance level).

The table 3 demonstrates that for the combined data of twins and siblings, the negative association exists between attend and health, between attend and health_m and between ident_relig and health_m. We can see that although the second association is not significant for twin data as shown in table 2 , it is for combined data. As sample size increases, it is more likely to find a significant association.

\subsection{Pearson Chi-square tests}

If we drop the ordinal information in two ordinal variables of religiosity and health come and treat them as categorical variables, we can use standard Pearson Chi-square tests to measure the relationship between these two categorical variables.

The results of this test for 6 pairs of religiosity variable (attend, ident_relig and born) and health outcome variable (health and health_m) are given in table 5, showing significant associations between attend and health (at 1\% level), between attend and health_m, and between ident_relig and health (at 10\% level). The absence of association between born and health or health_m apparently has something to do with the large number of missing values (791) for the variable born.

\subsection{Mantel-Haenszel Chi-Square Test}

Mantel-Haenszel chi-square statistic is appropriate only when both variables lie on an ordinal scale. The Mantel-Haenszel chi-square statistic tests the alternative hypothesis that there is a 
linear association between the row variable and the column variable. Both variables must lie on an ordinal scale. The Mantel-Haenszel chi-square statistic is computed as

$$
Q_{M H}=(n-1) r^{2}
$$

where $r^{2}$ is the Pearson correlation between the row variable and the column variable.

Under the null hypothesis of no association, $Q_{M H}$ has an asymptotic chi-square distribution with one degree of freedom.

The result of Mantel-Haenszel Chi-Square Test presented in the second panel of table 5 shows a similar pattern of significance with that of the first panel of Pearson test result with the only exception of an additional strongly significant association between level of identification with religious group and mental health index score. Since MH test takes into account ordinal information in data while Pearson test does not, it is a better test than Pearson Chi-square test.

\subsection{Kruskal Wallis test}

The Kruskal Wallis test is used when we have one independent variable with two or more levels and an ordinal dependent variable. In other words, it is the non-parametric version of ANOVA. It is also a generalized form of the Mann-Whitney test method, as it permits two or more groups.

The results in the third panel of table 5 indicate that there is a statistically significant difference in physical health index score among the five levels of religious attendance frequency (chi-square statistic $=21.47, \mathrm{p}=0.0003$ ). Similarly there is a statistically significant difference in mental health index score among the four levels of religious identification index (chi-square $=11.45, \mathrm{p}=0.0095$ ), which is consistent with the result of $\mathrm{MH}$ test above.

\subsection{Cochran-Mantel-Haenszel Test}

The above tests do not control for any covariate so they do not take into account that respondents within a family are correlated and thus more familiar than those from other families. To address this, I also use Cochran-Mantel-Haenszel statistics. The MantelHaenszel procedure provides statistics to detect general association, mean score 
differences, and linear correlation as alternatives to the null hypothesis of no association in the examination of sets of contingency Tables. This test potentially removes the confounding influence of the explanatory variables that comprise the stratification and provides a gain of power for detecting associations by comparing like subjects, in other words, the test is targeted at detecting average effects across strata (Stokes et al., 1995). In our setting, the response level is ordinally scaled; therefore, the alternative hypothesis is that there is a location shift for these mean scores across levels of religious involvement, say religious attendance frequency. The Mean Score statistic, which has 4 degrees of freedom, for the five frequencies of variable attend, will be used for the comparison of the means of health score for the five frequencies across our specified strata (family). The Linear Association statistic, which has one degree of freedom, will be used for the comparison of a linear trend due to attendance across our specified strata. The results of this test in table 6 show that both attendance frequency and religious identification index have a significant linear association with health outcomes, indicating that there is a linear trend of health outcomes due to attendance or religious identification across strata of family. When people attend church services more often or have higher level of identification with religious group, they tend to have better health physically and mentally. In addition, there is a general association between born and health and a significant difference (at 10\% level) in mean score of mental health across levels of religious identification.

\subsection{Random Intercept Model for Cumulative Logistic Regression}

As the table 7 shows, all proportional odds assumption tests fail for ordinal logistic

regressions for the two ordinal response variables: health and health_m. Since the assumption cannot be met, proportional odds model for ordered logistic regression cannot be used. In addition, ordered logit model cannot account for within family correlations. As an alternative, I use a random intercept model for cumulative logistic regression by using PROC GLIMMIX in SAS, which is essential running a generalized linear mixed model to data with correlations and where the response is not necessarily normally distributed. 
The random intercept model, which captures random effect of family, has the form $\log \left(\frac{P_{f t}}{1-P_{f t}}\right)=\beta x_{f t}+v z_{f}+\alpha_{f}$

where $\mathrm{E}\left({ }^{\alpha_{f}}\right)=0, \operatorname{Var}\left({ }^{\alpha_{f}}\right)=\tau^{2}, \alpha_{f}$ is independent of $x_{f t}$ and $z_{f}$, and $\alpha_{f}$ is normally distributed.

Here subscript $f$ indexes family, $t$ indexes each twin or sibling in each family. $\beta$ and $\gamma$ are row vectors of coefficients. ${ }^{\alpha}$ represents family-specific heterogeneity that vary across families but not within families. The estimate of variable attend in table 8 implies that people going to church about once a week have $1.39(=\exp (0.3284))$ times greater odds of achieving higher physical health score (better health status) than people never going to church. Similarly, people whose identification level with religious group is "very" have $1.36(=\exp (0.304))$ times greater odds of achieving higher mental health score than people whose identification level with religious group is "not at all". A marginally significant relationship is also found between religious group identification and physical health score at $10 \%$ level.

\section{FE MODEL TO CONTROL FOR OVB}

According to $\mathrm{WHO}$, the determinants of health include the following factors:

1. Income and social status - higher income and social status are linked to better health. The greater the gap between the richest and poorest people, the greater the differences in health.

2. Education - low education levels are linked with poor health, more stress and lower self-confidence.

3. Physical environment - safe water and clean air, healthy workplaces, safe houses, communities and roads all contribute to good health.

4. Employment and working conditions - people in employment are healthier, particularly those who have more control over their working conditions 
5. Social support networks - greater support from families, friends and communities is linked to better health.

6. Culture - customs and traditions, and the beliefs of the family and community all affect health.

7. Genetics - inheritance plays a part in determining lifespan, healthiness and the likelihood of developing certain illnesses.

8. Personal behaviour and coping skills - balanced eating, keeping active, smoking, drinking, and how we deal with life's stresses and challenges all affect health.

9. Health services - access and use of services that prevent and treat disease influences health

10. Gender - Men and women suffer from different types of diseases at different ages. Among these factors, data for factor 3 and 6 are unavailable to us and factor 7 unobservable. If we omit them in a simple OLS regression for the outcome of health status, the estimate of the variable of interest may be biased because the variable may be correlated with the residual that subsumes the effects of these omitted variables. Previous studies on the health effect of religion just ignored this omitted variable bias.

It is worthy to note that these factors unavailable in data are generally shared by family members within a family. Siblings or twins generally have the same growth environment, have the same social networks, receive the same social support from the same family, friends and community, adapt to the same customs and traditions. Most importantly, siblings, particularly twins have far more similar genetics than other people.

In demography, it is common to use twins or siblings to control for unobserved family and background characteristics. Differencing across siblings removes family effects that may be correlated with the explanatory variables. For example, Geronimus and Korenman (1992) use pairs of sisters to study the effects of teen childbearing on future economic outcomes.

The two subsamples of twins and siblings in our data provide us with an opportunity to use within-family differencing to control for omitted variables: physical environment, family support, community and social environment, inheritance and other background characteristics shared by all the family members of a family. Obviously, twin data have 
higher similarity between twins in terms of these variables than sibling data between siblings. Particularly, for those identical twins (not fraternal twins), the effects of genes on health are almost the same thus can be eliminated.

Using twin data, our model for attend is

$y_{f t}=\beta_{0}+\delta_{0} t_{\text {win } 2}+\beta_{1}$ attend $_{f t}+$ other $_{-}$factors $_{f t}+a_{f}+u_{f t}$

Where $y$ is health index, attend is an index for religious attendance frequency, subscript $\mathrm{f}$ indexes family and $t$ indexes a twin within the family. The intercept for the first twin is $\beta 0$, and the intercept for the second twin is $\beta 0+\delta 0$. The variable of interest is attend. The unobserved variable ${ }^{a_{f}}$, which changes only across family, is an unobserved family/inheritance effect or a family fixed effect. The main concern in the analysis is that variable attend is correlated with the family effect. If so, an Ordinary Least Square (OLS) analysis that pools across families and twins gives a biased estimator of the effect of religious attendance on health index. Solving this problem is simple: for all families, difference (1) across twins to get

$$
\Delta y_{t}=\delta_{0}+\beta_{1} \Delta \text { attend }_{f}+\Delta \text { other_ } \text { factors }_{f}+\Delta u_{f}
$$

This removes the family or inheritance effect, ${ }^{a_{f}}$, and the resulting equation can be estimated by OLS regression.

For our data, response variables include health, health_m and days, the key variables of interest are religiosity measures, including attend, ident_relig and born. The choice of other control variables is based on 10 factors defined as determinants of health by WHO and shown before. Factor 1 is captured by variable income, factor 2 by education, factor 4 by working, Factor 5 by attend and ident_relig, factor 8 by alc_drug, anxiety, exercise and sad, factor 9 by insurance and ins_sp, and factor 10 by gender and age. The remaining three factors $(3,6$ and 7$)$ and part of factor 5 are controlled for by differencing across twins or siblings within a family. Here variable sad is included not only because it represents a part of factor $8:$ how people deal with life's stresses and challenges, but also it reflects an important hypothesized mechanism of health effect of religiosity: mood. 
Koenig and Vaillant (2009:123) hypothesized that regular church attendance would protect people against poor physical health because it would "increase one's level of contentment, including through increased social support, a more positive outlook on life, [and] increased hope and encouragement." They found that "better moods" explained some of the effect of church attendance on subsequent physical health. So including this variable can not only test the general idea that psychological resources could explain the influence of religion on physical health, but also test if it is the only channel through which religion affects health.

In addition, to control for reverse causality, I also include health16_, which is self-rated physical health score at 16 year-old. The inclusion of this variable makes it unlikely that the observed effect of religious attendance on health is only because healthy people go to church more often than unhealthy people as health implies higher mobility and higher physical ability to conduct social activities. Including a variable of baseline health status is a means of removing source of endogeneity other than omitted variable bias.

Because our final result is based on model (2) whose variables are all differences between twins/siblings, the nature of ordering in the ordinal variables is lost after betweentwin/sibling differencing, so all the differences of either dependent variable or independent variables (regardless of ordinal variable or dummy variable or continuous variable in raw data) will be taken as numerical continuous variables and OLS regressions are applied to them. This treatment of ordinal variables is based on the assumption that the distance between each pair of consecutive levels of an ordinal variable is the same. Since all ordinal variables are subjective rating of the respondents in the survey, this assumption is reasonable.

\section{RESULTS OF THE FIXED EFFECT MODEL}

Table 9 and 10 show strong evidence of significantly negative impacts from two religiosity variables (attend, ident_relig) to two health outcome variables ( $p$ health, health_m) and significantly positive effects from two religiosity variables to health outcome variable days, after controlling for other determinants of health defined by 
WHO and potential omitted variable bias. Although this is not always true for both twin data and sibling data separately, it can be seen from table 12 that these two effects are shown to be strong and robust for combined data of twins and siblings. The first relationship indicates that with the decrease in religious attendance frequency, health scores for both physical and mental health status are decreasing. In addition, with the decrease in degree of identification with religious group, health scores for both physical and mental health status are decreasing. For combined data, these two effects are significant at $1 \%$ level.

The second relationship implies that with the decrease in religious attendance frequency or degree of identification with respondent's religious group, the number of days when work is limited by health is increasing. Specifically, for twins data, every unit of increase in religious attendance frequency index leads to a decrease of about 4 days $(0.3052 * 12=3.66)$ every year when work is limited by health problem. Similarly, for twins data every unit of increase in degree of identification with religious group brings about a decrease of roughly 4 days $(0.3611 * 12=4.33)$ every year when work is limited by health.

The table 11 shows similar but weaker relationships for dummy variable born on physical health and days off work due to health, but not for mental health. On average, the people who have self perception of "born again" have physical health score 0.22 higher than the people who have not. The people who think themselves have had a turning point in life when committing to Jesus Christ have about 11 fewer days $(0.89 * 12=10.68)$ every year when work is limited by health problem, compared with people who do not think so. These effects however are only significant at $10 \%$ level, which of course has something to do with smaller sample size due to many missing values of variable born (792 vs. 255 of ident_relig and 254 of attend, see table 2). For combined data, the significance level for the second effect on days is raised to $5 \%$ as shown in table 12 .

\section{DISCUSSION ON THE MECHANISMS}


The explanatory variables used in this paper for health outcome response variables are chosen to reflect some proposed explanatory mechanisms of religion on health. For example, Son and Wilson (2011) proposed three possible mechanisms: 1) behaviors and lifestyles, 2) social networks and social support and 3) psychological factors. The first one is captured by variables alc_drug, and exercise, the second by attend and ident_relig and the third by anxiety and sad. The third mechanism is also captured by variable born. The results of table 9 to 11 show that the effects of born on health outcome variables are weaker than those of attend and ident_relig in terms of both significance level and number of health outcome variables affected significantly (no significant impact on health_m from born). This is partly because of the reduced sample size by missing values of the variable born, but at the same time, the significant estimates of born (at $10 \%$ level), which proxy psychological factors beneficial to health, support the view that religion enhances positive psychological resources, which in turn makes achieving good health easier (George, Ellison, and Larson 2002:195). Self perception of a turning point in life when committing to Jesus Christ is not a visible change in behaviors or lifestyles, nor is it related to social networks and social support. However, as Son and Wilson (2011: 590) pointed out, "religious beliefs instill the feeling that a divine being loves you and that you have a personal relationship with a divine other, which enhances self-worth, efficacy, and mastery... a belief that God's will is expressed in events instills a sense of purpose in and control over one's life; and religious guidance fosters a feeling of calm, reassurance, and ability to cope with stress stemming from illnesses, portraying them as opportunities for spiritual growth or as part of a larger plan (Ellison and Levin 1998:707; Krause 2010; Musick and Worthen 2010:254; Oman and Thoresen 2005:446; Ryff, Singer, and Love 2004:95)"'.

Since for tables 11, the model has included variables anxiety and sad to control for psychological factors, the significant estimates of variable born imply that "better moods" cannot fully explain the health effect of the changes in psychological resources brought about by religious belief of Christianity. Mood is not the only channel of psychological factors that work to affect health. Similarly for tables 9 to 11, the model has included variables alc_drug, and exercise to control for effects on behaviors and lifestyles, the 
results of these tables also imply that behaviors and lifestyles is not the only mechanism through which religion affects health.

Because table 9 and 10 both have used between-twins or between-siblings differences to partly control for social networks and social support (which cannot be fully captured by variable attend or ident_relig and is often common to twins or siblings), the significant estimates for attend and ident_relig suggest that social networks /support alone cannot be the only channel through which religion works on health. So overall, our empirical evidences support the combination of the three mechanisms proposed by Son and Wilson (2001) for health effects of religion, specifically Christianity. However, the data also suggests that either other channels through which religiosity affects health may exist or the mechanism of psychological resources goes far beyond of "good moods" and contains much more plentiful and profound connotations that is relevant to health, such as pure faith of God.

\section{CONCLUSION}

To account for potential bias from heterogeneity in hereditary factors and family background or other endogeneity, I use the within-twin and within-siblings differences to estimate the effects of Christian faith on three health outcome variables by applying fixed effect model to the data of twins and siblings from the first wave of the National Survey of Midlife in the United States (1995). Both this model and other non-model-based statistical tests confirm significant positive health effects of religiosity of Christianity. The results also support the three explanatory mechanisms of religion on health proposed by Son and Wilson (2011): 1) behaviors and lifestyles, 2) social networks and 3) social support and psychological resources. However, the data also suggests that either other channels through which religiosity affects health may exist or the mechanism of psychological resources goes far beyond of "good moods" and contains much more plentiful and profound connotations that is relevant to health. 
Table 1 Variable definitions and values taken by variable

\begin{tabular}{|c|c|c|c|}
\hline Variable & Label & Question & Value \\
\hline Age & $\begin{array}{l}\text { Respondent's } \\
\text { age }\end{array}$ & & \\
\hline Alc_drug & $\begin{array}{l}\text { Alcohol or } \\
\text { drug } \\
\text { problems }\end{array}$ & $\begin{array}{l}\text { In the past twelve months, have you experienced or } \\
\text { been treated for alcohol or drug problems? }\end{array}$ & $1=$ yes, $0=$ no \\
\hline Anxiety & $\begin{array}{l}\text { Anxiety } \\
\text { attack }\end{array}$ & $\begin{array}{l}\text { During the past } 12 \text { months, did you ever have a spell } \\
\text { or an attack when you felt } \\
\text { Frightened, anxious, or very uneasy? }\end{array}$ & \\
\hline Attend & $\begin{array}{l}\text { Attend } \\
\text { religious } \\
\text { service }\end{array}$ & $\begin{array}{l}\text { How often do you usually attend religious or spiritual } \\
\text { services? }\end{array}$ & $\begin{array}{l}\text { 1=more than } \\
\text { once a } \\
\text { week, } 2=\text { abou } \\
\text { t once a } \\
\text { week,3=one } \\
\text { to three times } \\
\text { a } \\
\text { month,4=less } \\
\text { than once a } \\
\text { month,5=nev } \\
\text { er }\end{array}$ \\
\hline Bmi & $\begin{array}{l}\text { Body mass } \\
\text { index }\end{array}$ & & Range: $9-24$ \\
\hline Born & $\begin{array}{l}\text { Born again } \\
\text { christian }\end{array}$ & $\begin{array}{l}\text { Have you been "born again," that is, had a turning } \\
\text { point in your life when you committed yourself to } \\
\text { Jesus Christ? }\end{array}$ & $1=$ yes, $0=$ no \\
\hline Days & $\begin{array}{l}\text { Days work } \\
\text { limited by } \\
\text { health }\end{array}$ & $\begin{array}{l}\text { In the past } 30 \text { days, how many days were you totally } \\
\text { unable to go to work or carry out your } \\
\text { Normal household work activities because of your } \\
\text { physical health or mental health? }\end{array}$ & Range: $0-30$ \\
\hline $\begin{array}{l}\text { Educatio } \\
\mathrm{n}\end{array}$ & $\begin{array}{l}\text { R education } \\
\text { level }\end{array}$ & $\begin{array}{l}\text { What is the highest grade of school or year of college } \\
\text { you completed? }\end{array}$ & Range: $1-12$ \\
\hline Exercise & $\begin{array}{l}\text { Exercise or } \\
\text { movement } \\
\text { therapy } \\
\text { used }\end{array}$ & $\begin{array}{l}\text { In the past } 12 \text { months, have you used exercise or } \\
\text { movement therapy to improve health? }\end{array}$ & $1=$ yes, $0=$ no \\
\hline Gender & $\begin{array}{l}\text { Gender of } \\
\text { respondent }\end{array}$ & & $\begin{array}{l}1=\text { male } \\
0=\text { female }\end{array}$ \\
\hline Health & $\begin{array}{l}\text { Physical } \\
\text { health }\end{array}$ & In general, would you say your physical health is...? & $\begin{array}{l}1 \text { = poor, } 2= \\
\text { fair, } 3=\text { good, } 4 \\
=\text { very } \\
\text { Good, } 5= \\
\text { excellent; } \\
\text { range: } 1-5\end{array}$ \\
\hline
\end{tabular}


Table 1 Variable definition and values taken by variable (Continued)

\begin{tabular}{|c|c|c|c|}
\hline Variable & Label & Question & Value \\
\hline Health16_ & $\begin{array}{l}\text { Physical } \\
\text { health at } \\
16\end{array}$ & $\begin{array}{l}\text { How was your physical health at the time } \\
\text { you were } 16 \text { years old? }\end{array}$ & $\begin{array}{l}1=\text { poor, } \\
2=\text { fair,3=good, } 4=v \\
\text { ery } \\
\text { good, } 5=\text { excellent; } \\
\text { range: } 1-5\end{array}$ \\
\hline Health m & $\begin{array}{l}\text { Mental or } \\
\text { emotional } \\
\text { health }\end{array}$ & $\begin{array}{l}\text { What about your mental or emotional } \\
\text { health? }\end{array}$ & $\begin{array}{l}1=\text { poor, } \\
2=\text { fair, } 3=\text { good, } 4=v \\
\text { ery } \\
\text { good, } 5=\text { excellent; } \\
\text { range: } 1-5\end{array}$ \\
\hline Ident_relig & $\begin{array}{l}\text { Identify } \\
\text { with a } \\
\text { religious } \\
\text { group }\end{array}$ & $\begin{array}{l}\text { How closely do you identify with being a } \\
\text { member of your religious group? }\end{array}$ & $\begin{array}{l}1=\text { very, } 2=\text { somew } \\
\text { hat, } 3=\text { not } \\
\text { very, } 4=\text { not at all }\end{array}$ \\
\hline Income & $\begin{array}{l}\text { Log of } \\
\text { income } \\
\text { rank }\end{array}$ & $\begin{array}{l}\text { What is your personal earnings income in } \\
\text { the past } 12 \text { months, before taxes }\end{array}$ & $\begin{array}{l}\text { A 31-category } \\
\text { measure of personal } \\
\text { income }\end{array}$ \\
\hline Ins_sp & $\begin{array}{l}\text { Private } \\
\text { through } \\
\mathrm{s} / \mathrm{p} \\
\text { employer }\end{array}$ & $\begin{array}{l}\text { Are you currently covered by private } \\
\text { insurance through your spouse or partner's } \\
\text { current or } \\
\text { Former employer }\end{array}$ & \\
\hline Insurance & $\begin{array}{l}\text { Private } \\
\text { through } \\
\text { employer }\end{array}$ & $\begin{array}{l}\text { Are you currently covered by private } \\
\text { insurance through your own current or } \\
\text { former } \\
\text { Employer }\end{array}$ & $1=y e s, 0=$ no \\
\hline Marital & $\begin{array}{l}\text { Marital } \\
\text { status }\end{array}$ & $\begin{array}{l}\text { Are you married, separated, divorced, } \\
\text { widowed, or never married? }\end{array}$ & $\begin{array}{l}1=\text { married, } 2=\text { sepe } \\
\text { rated, } 3=\text { divorced, } \\
4=\text { widowed, } 5=\text { ne } \\
\text { ver married; } \\
\text { range: } 1-5\end{array}$ \\
\hline Sad & $\begin{array}{l}\text { Felt sad } \\
2+\text { weeks }\end{array}$ & $\begin{array}{l}\text { During the past } 12 \text { months, was there ever a } \\
\text { time when you felt sad, blue, or depressed } \\
\text { for } \\
\text { Two weeks or more in a row? }\end{array}$ & $1=y e s, 0=$ no \\
\hline Working & $\begin{array}{l}\text { Working } \\
\text { now }\end{array}$ & Are you working now for pay & $1=$ yes, $0=$ no \\
\hline
\end{tabular}


Table 2 Descriptive statistic of the variables used

\begin{tabular}{|c|c|c|c|c|c|c|}
\hline Variable & $\mathrm{N}$ & NMiss & Mean & Std Dev & Minimum & Maximum \\
\hline days & 2741 & 31 & 0.8508 & 3.9947 & 0 & 30 \\
\hline health & 2766 & 6 & 3.6085 & 0.9643 & 1 & 5 \\
\hline health_m & 2769 & 3 & 3.8675 & 0.9156 & 1 & 5 \\
\hline attend & 2518 & 254 & 3.0651 & 1.3705 & 1 & 5 \\
\hline ident_relig & 2517 & 255 & 2.1986 & 1.0395 & 1 & 4 \\
\hline born & 1980 & 792 & 0.4753 & 0.4995 & 0 & 1 \\
\hline marital & 2769 & 3 & 1.7916 & 1.3893 & 1 & 5 \\
\hline gender & 2772 & 0 & 0.6670 & 1.3635 & 0 & 8 \\
\hline education & 2761 & 11 & 6.7139 & 2.4318 & 1 & 12 \\
\hline bmi & 2452 & 320 & 26.6270 & 5.1830 & 15.45 & 57.441 \\
\hline alc_drug & 2532 & 240 & 0.0201 & 0.1405 & 0 & 1 \\
\hline anxiety & 2765 & 7 & 0.1295 & 0.3358 & 0 & 1 \\
\hline income & 2420 & 352 & 2.5719 & 0.9715 & 0 & 3.434 \\
\hline health16_ & 2770 & 2 & 4.4184 & 0.8170 & 1 & 5 \\
\hline working & 2750 & 22 & 0.6556 & 0.4752 & 0 & 1 \\
\hline insurance & 2361 & 411 & 0.5540 & 0.4972 & 0 & 1 \\
\hline ins_sp & 2307 & 465 & 0.3017 & 0.4591 & 0 & 1 \\
\hline exercise & 2521 & 251 & 0.1599 & 0.3665 & 0 & 1 \\
\hline sad & 2763 & 9 & 0.2381 & 0.4508 & 0 & 1 \\
\hline age & 2721 & 51 & 46.2635 & 12.4220 & 24 & 75 \\
\hline
\end{tabular}

$\mathrm{N}=$ Number of observations, NMiss=Number of missing values, Std Dev=Standard Deviation 
Table 3 The frequency distribution of physical and mental health outcomes by religiosity variables

\begin{tabular}{|c|c|c|c|c|c|}
\hline \multicolumn{6}{|c|}{ attend(col)*health(row) } \\
\hline level & 1 & 2 & 3 & 4 & 5 \\
\hline 1 & 6 & 41 & 122 & 137 & 59 \\
\hline 2 & 13 & 52 & 208 & 284 & 147 \\
\hline 3 & 2 & 35 & 101 & 114 & 74 \\
\hline 4 & 8 & 55 & 214 & 247 & 111 \\
\hline 5 & 18 & 61 & 161 & 169 & 74 \\
\hline \multicolumn{6}{|c|}{ attend(col)*health_m(row) } \\
\hline level & 1 & 2 & 3 & 4 & 5 \\
\hline 1 & 0 & 22 & 95 & 135 & 114 \\
\hline 2 & 5 & 26 & 201 & 272 & 202 \\
\hline 3 & 3 & 17 & 94 & 118 & 95 \\
\hline 4 & 3 & 33 & 179 & 245 & 176 \\
\hline 5 & 0 & 34 & 162 & 155 & 129 \\
\hline \multicolumn{6}{|c|}{ ident_relig(col)*health(row) } \\
\hline level & 1 & 2 & 3 & 4 & 5 \\
\hline 1 & 13 & 71 & 250 & 305 & 154 \\
\hline 2 & 10 & 89 & 251 & 286 & 153 \\
\hline 3 & 9 & 45 & 187 & 223 & 103 \\
\hline 4 & 15 & 38 & 117 & 138 & 55 \\
\hline \multicolumn{6}{|c|}{ ident_relig(col)*health_m(row) } \\
\hline level & 1 & 2 & 3 & 4 & 5 \\
\hline 1 & 5 & 30 & 209 & 301 & 250 \\
\hline 2 & 4 & 44 & 232 & 290 & 221 \\
\hline 3 & 1 & 33 & 169 & 206 & 156 \\
\hline 4 & 1 & 24 & 119 & 128 & 91 \\
\hline \multicolumn{6}{|c|}{ born(col)*health(row) } \\
\hline level & 1 & 2 & 3 & 4 & 5 \\
\hline 0 & 18 & 88 & 341 & 385 & 206 \\
\hline 1 & 17 & 102 & 293 & 362 & 163 \\
\hline \multicolumn{6}{|c|}{ born(col)*health_m(row) } \\
\hline level & 1 & 2 & 3 & 4 & 5 \\
\hline 0 & 3 & 52 & 289 & 389 & 305 \\
\hline 1 & 8 & 56 & 260 & 342 & 275 \\
\hline
\end{tabular}


Table 4 Correlation of health outcome variables and religiosity variables for the twins data and siblings data together

\begin{tabular}{|c|c|c|c|c|c|c|c|c|}
\hline data & correlation & variable & attend & p_attend & ident_relig & p_ident_relig & born & p_born \\
\hline all & Kendall Tau & health & -0.0402 & $0.015^{*}$ & & & & \\
\hline all & Spearman & health & -0.0485 & $0.0151^{*}$ & & & & \\
\hline all & Kendall Tau & health & & & -0.0268 & 0.1129 & & \\
\hline all & Spearman & health & & & -0.0317 & 0.1127 & & \\
\hline all & Kendall Tau & health & & & & & -0.0257 & 0.2157 \\
\hline all & Spearman & health & & & & & -0.0279 & 0.2158 \\
\hline all & Kendall Tau & health_m & -0.0404 & $0.0154^{*}$ & & & & \\
\hline all & Spearman & health_m & -0.0482 & $0.0157^{*}$ & & & & \\
\hline all & Kendall Tau & health_m & & & -0.0549 & $0.0013 * *$ & & \\
\hline all & Spearman & health_m & & & -0.0643 & $0.0013 * *$ & & \\
\hline all & Kendall Tau & health_m & & & & & -0.0125 & 0.5510 \\
\hline all & Spearman & health_m & & & & & -0.0134 & 0.5511 \\
\hline
\end{tabular}


Table 5 Three statistical tests of associations between religiosity and health outcomes

\begin{tabular}{lrrl}
\hline Variable pair & statistic & p_value & data \\
\hline \multicolumn{4}{c}{ Pearson Chi-square test result } \\
(attend, health) & $\mathbf{3 8 . 0 5 6}$ & $\mathbf{0 . 0 0 1 5 ^ { * * }}$ & all \\
(ident_relig, health) & $\mathbf{2 0 . 5 7 7 7}$ & $\mathbf{0 . 0 5 6 9 +}$ & all \\
(born, health) & 5.2619 & 0.2615 & all \\
(attend, health_m) & $\mathbf{2 3 . 8 5 6 8}$ & $\mathbf{0 . 0 9 2 7 +}$ & all \\
(ident_relig, health_m) & 15.6295 & 0.2088 & all \\
(born, health_m) & 3.781 & 0.4365 & all \\
\hline \multicolumn{4}{c}{ Mantel-Haenszel Chi-Square test result } \\
(attend, health) & $\mathbf{6 . 5 8 5 6}$ & $\mathbf{0 . 0 1 0 3 ^ { * }}$ & all \\
(ident_relig, health) & $\mathbf{3 . 8 4 0 1}$ & $\mathbf{0 . 0 5 +}$ & all \\
(born, health) & 1.903 & 0.1677 & all \\
(attend, health_m) & $\mathbf{5 . 4 6 1 2}$ & $\mathbf{0 . 0 1 9 4 *}$ & all \\
(ident_relig, health_m) & $\mathbf{9 . 6 5 9 7}$ & $\mathbf{0 . 0 0 1 9 * *}$ & all \\
(born, health_m) & 0.7368 & 0.3907 & all \\
\hline \multicolumn{4}{c}{ Kruskal Wallis test result } \\
(health, attend) & $\mathbf{2 1 . 4 7 2 1 2}$ & $\mathbf{0 . 0 0 0 3 * *}$ & all \\
(health, ident_relig) & 5.348829 & 0.148 & all \\
(health, born) & 1.532601 & 0.2157 & all \\
(health_m, attend) & 7.045428 & 0.1335 & all \\
(health_m, ident_relig) & $\mathbf{1 1 . 4 5 1 9 4 2}$ & $\mathbf{0 . 0 0 9 5 * *}$ & all \\
(health_m, born) & 0.3556 & 0.551 & all \\
\hline
\end{tabular}

$+\mathrm{p}<0.10 ;{ }^{*} \mathrm{p}<0.05 ;{ }^{* *} \mathrm{p}<0.01$. 
Table $6 \mathrm{CMH}$ test result

\begin{tabular}{llrrr}
\hline Association & Alternative Hypothesis & DF & \multicolumn{1}{c}{ Value } & P value \\
\hline attend * health & Nonzero Correlation & 1 & $\mathbf{3 . 8 7 1 8}$ & $\mathbf{0 . 0 4 9 1}$ \\
attend * health & Row Mean Scores Differ & 4 & 6.002 & 0.199 \\
attend * health & General Association & 16 & 15.2609 & 0.5056 \\
attend * health_m & Nonzero Correlation & 1 & $\mathbf{3 . 5 5 1 7}$ & $\mathbf{0 . 0 5 9 5}$ \\
attend * health_m & Row Mean Scores Differ & 4 & 6.2704 & 0.1798 \\
attend * health_m & General Association & 16 & 13.9798 & 0.6002 \\
ident_relig* health & Nonzero Correlation & 1 & $\mathbf{5 . 2 5 8 4}$ & $\mathbf{0 . 0 2 1 8}$ \\
ident_relig* health & Row Mean Scores Differ & 3 & 5.2691 & 0.1531 \\
ident_relig* health & General Association & 12 & 12.0995 & 0.4377 \\
ident_relig* health_m & Nonzero Correlation & 1 & $\mathbf{5 . 5 5 0 1}$ & $\mathbf{0 . 0 1 8 5}$ \\
ident_relig* health_m & Row Mean Scores Differ & 3 & $\mathbf{6 . 6 0 1 3}$ & $\mathbf{0 . 0 8 5 8}$ \\
ident_relig* health_m & General Association & 12 & 11.7049 & 0.4697 \\
born * health & Nonzero Correlation & 1 & 0.7901 & 0.3741 \\
born * health & Row Mean Scores Differ & 1 & 0.7901 & 0.3741 \\
born* health & General Association & 4 & $\mathbf{8 . 3 6 9 4}$ & $\mathbf{0 . 0 7 8 9}$ \\
born * health_m & Nonzero Correlation & 1 & 1.1169 & 0.2906 \\
born * health_m & Row Mean Scores Differ & 1 & 1.1169 & 0.2906 \\
born * health_m & General Association & 4 & 4.3059 & 0.3662 \\
\hline
\end{tabular}

$\mathrm{CMH}=$ Cochran-Mantel-Haenszel. DF=Degree of freedom. 
Table 7 Test of proportional odd assumption for ordered logistic regression

\begin{tabular}{lllll}
\hline ChiSq & DF & P value & depvar & indepvar \\
\hline 194.7294 & 99 & $<.0001$ & health & attend \\
227.0168 & 99 & $<.0001$ & health_m & attend \\
199.2921 & 96 & $<.0001$ & health & ident_relig \\
215.0742 & 96 & $<.0001$ & health_m & ident_relig \\
157.034 & 90 & $<.0001$ & health & born \\
191.6396 & 90 & $<.0001$ & health_m & born \\
\hline
\end{tabular}

ChiSq= Chi square statistic, DF=Degree of freedom, depvar $=$ dependent variable, indepvar=independent variable

Table 8 Random intercept cumulative logit model

\begin{tabular}{|c|c|c|c|c|c|c|c|c|}
\hline attend & Estimate & StdErr & Probt & Nobs & depvar & indepvar & ident_relig & born \\
\hline 1 & 0.2623 & 0.1739 & 0.1318 & 2011 & health & attend & & \\
\hline 2 & 0.3284 & 0.144 & 0.0229 & 2011 & health & attend & & \\
\hline 3 & 0.2592 & 0.1689 & 0.1254 & 2011 & health & attend & & \\
\hline 4 & 0.1839 & 0.1412 & 0.193 & 2011 & health & attend & & \\
\hline 5 & 0 & & & 2011 & health & attend & & \\
\hline 1 & 0.1592 & 0.1712 & 0.3529 & 2011 & health_m & attend & & \\
\hline 2 & -0.02824 & 0.1416 & 0.842 & 2011 & health_m & attend & & \\
\hline 3 & -0.08917 & 0.1668 & 0.5931 & 2011 & health_m & attend & & \\
\hline 4 & -0.06077 & 0.1396 & 0.6635 & 2011 & health_m & attend & & \\
\hline 5 & 0 & & & 2011 & health_m & attend & & \\
\hline & 0.2624 & 0.1575 & 0.0961 & 2015 & health & ident_relig & 1 & \\
\hline & 0.0589 & 0.1528 & 0.7 & 2015 & health & ident_relig & 2 & \\
\hline & 0.1962 & 0.158 & 0.2148 & 2015 & health & ident_relig & 3 & \\
\hline & 0 & & & 2015 & health & ident_relig & 4 & \\
\hline & 0.304 & 0.1547 & 0.0498 & 2015 & health_m & ident_relig & 1 & \\
\hline & 0.1498 & 0.1505 & 0.3199 & 2015 & health_m & ident_relig & 2 & \\
\hline & 0.1339 & 0.1555 & 0.3896 & 2015 & health_m & ident_relig & 3 & \\
\hline & 0 & & & 2015 & health_m & ident_relig & 4 & \\
\hline & -0.07678 & 0.112 & 0.4935 & 1584 & health & born & & 0 \\
\hline & 0 & & & 1584 & health & born & & 1 \\
\hline & -0.03929 & 0.107 & 0.7136 & 1585 & health_m & born & & 0 \\
\hline & 0 & & & 1585 & health $\mathrm{m}$ & born & & 1 \\
\hline
\end{tabular}

StdErr= standard error, Nobs=number of observations used, depvar=dependent variable, indepvar=independent variable. All the regressions include the following 13 covariates: marital, gender, education, bmi, alc_drug, anxiety, income, health16_,working, insurance, ins_sp, exercise, sad. 
Table 9 The result of Fixed Effect model (2) for attend

\begin{tabular}{|c|c|c|c|c|c|c|}
\hline \multirow{2}{*}{$\begin{array}{l}\text { Data } \\
\text { variable }\end{array}$} & \multicolumn{3}{|c|}{ Twins } & \multicolumn{3}{|c|}{ Siblings } \\
\hline & P_health & M_health & days & P_health & M_health & days \\
\hline & -0.0648 & -0.042 & 0.3053 & -0.1681 & -0.1754 & 0.3423 \\
\hline \multirow[t]{2}{*}{ attend } & $(0.033)+$ & $(0.032)$ & $(0.1313)^{*}$ & $(0.0525)^{* *}$ & $(0.054)^{* *}$ & $(0.2332)$ \\
\hline & & & & -0.0118 & -0.0196 & -0.0504 \\
\hline \multirow[t]{2}{*}{ age } & -- & -- & -- & $(0.0093)$ & $(0.0095)^{*}$ & $(0.0412)$ \\
\hline & -0.4546 & -0.2765 & -1.3875 & -0.0844 & -0.7926 & -1.7601 \\
\hline \multirow[t]{2}{*}{ alc_drug } & $(0.2609)+$ & $(0.2518)$ & $(1.0667)$ & $(0.3692)$ & $(0.3798)^{*}$ & (1.6275) \\
\hline & -0.2376 & -0.2417 & 0.3334 & -0.0932 & -0.3843 & -0.2434 \\
\hline \multirow[t]{2}{*}{ anxiety } & $(0.1054)^{*}$ & $(0.1011)^{*}$ & $(0.416)$ & $(0.1693)$ & $(0.1742)^{*}$ & $(0.7651)$ \\
\hline & -0.016 & 0.0077 & -0.0241 & -0.0429 & -0.0163 & 0.1138 \\
\hline \multirow[t]{2}{*}{ bmi } & $(0.0091)+$ & $(0.0089)$ & $(0.0363)$ & $(0.0111)^{* *}$ & $(0.0114)$ & $(0.0498)^{*}$ \\
\hline & -0.0099 & -0.0137 & 0.0068 & -0.0136 & 0.0092 & 0.047 \\
\hline \multirow[t]{2}{*}{ education } & $(0.0216)$ & $(0.0208)$ & $(0.0858)$ & $(0.0283)$ & $(0.0291)$ & $(0.1253)$ \\
\hline & -0.2039 & 0.1256 & 1.3125 & -0.025 & 0.1308 & -0.354 \\
\hline \multirow[t]{2}{*}{ exercise } & $(0.0937)^{*}$ & $(0.0904)$ & $(0.3785)^{* *}$ & $(0.1498)$ & $(0.1541)$ & $(0.6601)$ \\
\hline & 0.0691 & -0.0244 & 0.3502 & 0.0437 & -0.0442 & -0.2249 \\
\hline \multirow[t]{2}{*}{ gender } & $(0.0976)$ & $(0.095)$ & $(0.3876)$ & $(0.1258)$ & $(0.1294)$ & $(0.5595)$ \\
\hline & 0.218 & 0.3572 & 0.3069 & 0.2478 & 0.3019 & -0.1625 \\
\hline \multirow[t]{2}{*}{ health16_ } & $(0.0473)^{* *}$ & $(0.0455)^{* *}$ & $(0.1885)$ & $(0.0707)^{* *}$ & $(0.0727)^{* *}$ & $(0.3115)$ \\
\hline & 0.0221 & 0.0638 & -0.4399 & -0.0137 & 0.1434 & 0.5183 \\
\hline \multirow[t]{2}{*}{ income } & $(0.0608)$ & $(0.0591)$ & $(0.2415)+$ & $(0.0811)$ & $(0.0834)+$ & $(0.3584)$ \\
\hline & 0.1424 & 0.1061 & -0.0604 & -0.0999 & 0.0245 & 0.4703 \\
\hline \multirow[t]{2}{*}{ ins_sp } & $(0.0827)+$ & $(0.0798)$ & $(0.3292)$ & $(0.1376)$ & $(0.1416)$ & $(0.6099)$ \\
\hline & 0.1639 & 0.0863 & 0.1516 & 0.1616 & 0.0852 & -0.3504 \\
\hline \multirow[t]{2}{*}{ insurance } & $(0.0871)+$ & $(0.0841)$ & $(0.3472)$ & $(0.1312)$ & $(0.135)$ & (0.5839) \\
\hline & 0.0259 & -0.0211 & -0.0044 & 0.0435 & -0.042 & -0.1992 \\
\hline \multirow[t]{2}{*}{ marital } & $(0.0292)$ & $(0.0284)$ & $(0.1163)$ & $(0.0489)$ & $(0.0503)$ & $(0.2181)$ \\
\hline & -0.3122 & -0.5595 & -0.043 & -0.2561 & -0.306 & 0.8837 \\
\hline \multirow[t]{2}{*}{ sad } & $(0.0886)^{* *}$ & $(0.0858)^{* *}$ & $(0.3559)$ & $(0.1372)+$ & $(0.1412)^{*}$ & $(0.6084)$ \\
\hline & 0.1052 & -0.0222 & 0.0435 & 0.0751 & -0.1913 & -1.1603 \\
\hline working & $(0.1045)$ & $(0.1008)$ & $(0.4163)$ & $(0.1459)$ & $(0.1501)$ & $(0.6518)+$ \\
\hline \multirow[t]{2}{*}{ Adj Rsq } & 0.086 & 0.1722 & 0.0265 & 0.1506 & 0.1894 & 0.0226 \\
\hline & 0.0287 & 0.0313 & -0.0403 & -0.1088 & -0.2184 & -0.0904 \\
\hline Intercept & $(0.0464)$ & $(0.0448)$ & $(0.1848)$ & $(0.075)$ & $(0.0772)^{* *}$ & $(0.3337)$ \\
\hline Nobs & 529 & 529 & 525 & 215 & 215 & 211 \\
\hline
\end{tabular}


Table 10 The result of FE model (2) for religious identification

\begin{tabular}{|c|c|c|c|c|c|c|}
\hline \multirow{2}{*}{$\begin{array}{l}\text { Data } \\
\text { variable }\end{array}$} & \multicolumn{3}{|c|}{ Twins } & \multicolumn{3}{|c|}{ Siblings } \\
\hline & P_health & M_health & days & P_health & M_health & days \\
\hline & -0.0652 & -0.1015 & 0.3611 & -0.171 & -0.1402 & 0.2652 \\
\hline \multirow[t]{2}{*}{ ident_relig } & $(0.0421)$ & $(0.0404)^{*}$ & $(0.168)^{*}$ & $(0.0611)^{* *}$ & $(0.0638)^{*}$ & $(0.2686)$ \\
\hline & & & & -0.0084 & -0.0154 & -0.0593 \\
\hline \multirow[t]{2}{*}{ age } & -- & -- & -- & (0.0091) & $(0.0095)$ & $(0.0404)$ \\
\hline & -0.4412 & -0.2757 & -1.4562 & -0.0932 & -0.8274 & -1.707 \\
\hline \multirow[t]{2}{*}{ alc_drug } & $(0.2602)+$ & $(0.2499)$ & (1.0659) & $(0.3712)$ & $(0.3879)^{*}$ & $(1.6302)$ \\
\hline & -0.2203 & -0.2221 & 0.2716 & -0.1042 & -0.4152 & -0.1919 \\
\hline \multirow[t]{2}{*}{ anxiety } & $(0.1047)^{*}$ & $(0.1)^{*}$ & $(0.4141)$ & (0.1701) & $(0.1778)^{*}$ & $(0.7658)$ \\
\hline & -0.0178 & 0.0054 & -0.0192 & -0.0404 & -0.0127 & 0.1081 \\
\hline \multirow[t]{2}{*}{ bmi } & $(0.0091)^{*}$ & $(0.0088)$ & $(0.0362)$ & $(0.0111)^{* *}$ & $(0.0116)$ & $(0.0496)^{*}$ \\
\hline & -0.0115 & -0.0168 & -0.001 & -0.02 & 0.0044 & 0.0574 \\
\hline \multirow[t]{2}{*}{ education } & $(0.0215)$ & $(0.0207)$ & $(0.0858)$ & $(0.0285)$ & (0.0298) & $(0.126)$ \\
\hline & -0.2013 & & 1.3162 & -0.0232 & 0.1281 & -0.3531 \\
\hline \multirow[t]{2}{*}{ exercise } & $(0.0936)^{*}$ & 0.11 (0.0899) & $(0.3789)^{* *}$ & $(0.1505)$ & $(0.1573)$ & $(0.6608)$ \\
\hline & 0.0579 & -0.008 & 0.3808 & 0.0313 & -0.0693 & -0.1842 \\
\hline \multirow[t]{2}{*}{ gender } & (0.0965) & $(0.0936)$ & $(0.3841)$ & $(0.1262)$ & $(0.1319)$ & $(0.5597)$ \\
\hline & 0.2063 & 0.3506 & 0.3463 & 0.2419 & 0.2746 & -0.128 \\
\hline \multirow[t]{2}{*}{ health16_ } & $(0.0469)^{* *}$ & $(0.045)^{* *}$ & $(0.1876)+$ & $(0.0705)^{* *}$ & $(0.0737)^{* *}$ & $(0.3096)$ \\
\hline & 0.025 & 0.0682 & -0.4565 & 0.0011 & 0.1574 & 0.4938 \\
\hline \multirow[t]{2}{*}{ income } & (0.0607) & $(0.0586)$ & $(0.2416)+$ & $(0.0816)$ & $(0.0852)+$ & $(0.3591)$ \\
\hline & 0.1543 & 0.1179 & -0.0982 & -0.1313 & -0.0207 & 0.5479 \\
\hline \multirow[t]{2}{*}{ ins_sp } & $(0.0823)+$ & (0.079) & $(0.3281)$ & $(0.1376)$ & (0.1438) & $(0.6074)$ \\
\hline & 0.1695 & 0.0864 & 0.1458 & 0.1677 & 0.0844 & -0.3548 \\
\hline \multirow[t]{2}{*}{ insurance } & $(0.0869)+$ & $(0.0834)$ & (0.3468) & $(0.1321)$ & $(0.1381)$ & $(0.586)$ \\
\hline & 0.0253 & -0.0171 & -0.0023 & 0.0233 & -0.0745 & -0.1473 \\
\hline \multirow[t]{2}{*}{ marital } & (0.0292) & $(0.0282)$ & $(0.1162)$ & (0.0479) & $(0.0501)$ & $(0.2126)$ \\
\hline & -0.3081 & -0.5509 & -0.0546 & -0.2621 & -0.2924 & 0.8765 \\
\hline \multirow[t]{2}{*}{ sad } & $(0.0884)^{* *}$ & $(0.0852)^{* *}$ & $(0.356)$ & $(0.138)+$ & $(0.1442)^{*}$ & $(0.6094)$ \\
\hline & 0.0985 & -0.0234 & 0.0727 & 0.0393 & -0.2227 & -1.0885 \\
\hline working & (0.1038) & (0.0997) & $(0.4146)$ & $(0.1464)$ & $(0.153)$ & $(0.6513)+$ \\
\hline \multirow[t]{2}{*}{ Adj Rsq } & 0.0837 & 0.1789 & 0.0249 & 0.138 & 0.1593 & 0.0157 \\
\hline & 0.0246 & 0.0288 & -0.0401 & -0.1237 & -0.2378 & -0.0594 \\
\hline Intercept & $(0.0463)$ & $(0.0445)$ & (0.1847) & $(0.0753)$ & $(0.0787)^{* *}$ & $(0.3334)$ \\
\hline Nobs & 530 & 530 & 526 & 216 & 216 & 212 \\
\hline
\end{tabular}


Table 11 The result of FE model (2) for born

\begin{tabular}{|c|c|c|c|c|c|c|}
\hline \multirow{2}{*}{$\begin{array}{l}\text { Data } \\
\text { variable }\end{array}$} & \multicolumn{3}{|c|}{ Twins } & \multicolumn{3}{|c|}{ Siblings } \\
\hline & P_health & M_health & days & P_health & M_health & days \\
\hline & 0.2171 & 0.1118 & -0.8908 & 0.0563 & -0.0971 & -1.2732 \\
\hline \multirow[t]{2}{*}{ born } & $(0.1116)+$ & $(0.1143)$ & $(0.5139)+$ & $(0.1546)$ & $(0.159)$ & $(0.7911)$ \\
\hline & & & & -0.0026 & -0.0169 & -0.0976 \\
\hline \multirow[t]{2}{*}{ age } & -- & -- & -- & $(0.0108)$ & $(0.0111)$ & $(0.0547)+$ \\
\hline & -0.189 & -0.1736 & -1.1613 & -0.3913 & -1.4604 & -3.0705 \\
\hline \multirow[t]{2}{*}{ alc_drug } & $(0.3259)$ & $(0.3338)$ & $(1.5812)$ & $(0.5812)$ & $(0.5978)^{*}$ & $(2.9192)$ \\
\hline & -0.1392 & -0.2812 & -0.2741 & -0.0972 & -0.645 & -0.3217 \\
\hline \multirow[t]{2}{*}{ anxiety } & (0.1317) & $(0.1338)^{*}$ & $(0.6012)$ & $(0.2275)$ & $(0.234)^{* *}$ & $(1.1836)$ \\
\hline & -0.0269 & 0.0032 & -0.0585 & -0.0564 & -0.0201 & 0.1204 \\
\hline \multirow[t]{2}{*}{ bmi } & $(0.0115)^{*}$ & $(0.0118)$ & $(0.0529)$ & $(0.0135)^{* *}$ & $(0.0139)$ & $(0.0694)+$ \\
\hline & 0.0328 & 0.0188 & 0.0269 & -0.0048 & 0.0396 & 0.0189 \\
\hline \multirow[t]{2}{*}{ education } & $(0.0259)$ & $(0.0265)$ & $(0.1196)$ & $(0.0352)$ & $(0.0362)$ & $(0.1774)$ \\
\hline & -0.2782 & 0.0365 & 1.292 & -0.0645 & 0.1116 & 0.0057 \\
\hline \multirow[t]{2}{*}{ exercise } & $(0.1129)^{*}$ & $(0.1157)$ & $(0.5273)^{*}$ & $(0.1773)$ & $(0.1823)$ & $(0.8877)$ \\
\hline & 0.104 & 0.0268 & 0.4274 & -0.0994 & -0.147 & -0.3766 \\
\hline \multirow[t]{2}{*}{ gender } & $(0.1205)$ & $(0.1234)$ & $(0.5556)$ & $(0.1582)$ & $(0.1627)$ & $(0.8037)$ \\
\hline & 0.1524 & 0.2552 & 0.3299 & 0.1084 & 0.2158 & -0.2006 \\
\hline \multirow[t]{2}{*}{ health16_ } & $(0.0575)^{* *}$ & $(0.0588)^{* *}$ & $(0.2649)$ & $(0.0909)$ & $(0.0935)^{*}$ & $(0.4556)$ \\
\hline & 0.0398 & 0.0774 & -0.7726 & 0.0365 & 0.1132 & 0.7498 \\
\hline \multirow[t]{2}{*}{ income } & $(0.0775)$ & $(0.0794)$ & $(0.3573)^{*}$ & $(0.1008)$ & $(0.1037)$ & $(0.5081)$ \\
\hline & 0.0897 & 0.0322 & -0.1475 & -0.3219 & 0.002 & 1.283 \\
\hline \multirow[t]{2}{*}{ ins_sp } & $(0.0974)$ & $(0.0998)$ & $(0.4484)$ & $(0.1746)+$ & $(0.1796)$ & $(0.8834)$ \\
\hline & 0.1937 & 0.0106 & 0.0716 & -0.0682 & 0.0488 & -0.322 \\
\hline \multirow[t]{2}{*}{ insurance } & $(0.1093)+$ & $(0.1119)$ & $(0.5078)$ & $(0.1587)$ & $(0.1632)$ & $(0.8081)$ \\
\hline & 0.0318 & -0.0079 & -0.0163 & 0.0043 & -0.0649 & -0.0043 \\
\hline \multirow[t]{2}{*}{ marital } & $(0.0365)$ & $(0.0374)$ & $(0.1688)$ & $(0.0575)$ & $(0.0591)$ & $(0.2904)$ \\
\hline & -0.2467 & -0.6411 & -0.1843 & -0.1607 & -0.2327 & 0.6387 \\
\hline \multirow[t]{2}{*}{ sad } & $(0.118)^{*}$ & $(0.1208)^{* *}$ & $(0.5449)$ & $(0.1844)$ & $(0.1897)$ & $(0.9393)$ \\
\hline & -0.0253 & -0.0095 & 0.6586 & 0.1427 & -0.2024 & -1.5381 \\
\hline working & $(0.1273)$ & $(0.1304)$ & $(0.5881)$ & $(0.1904)$ & (0.1959) & $(0.9726)$ \\
\hline \multirow[t]{2}{*}{ Adj Rsq } & 0.0783 & 0.1325 & 0.012 & 0.1206 & 0.1598 & 0.0366 \\
\hline & 0.049 & 0.0352 & -0.0616 & -0.054 & -0.215 & -0.4117 \\
\hline Intercept & $(0.0562)$ & $(0.0574)$ & $(0.2594)$ & $(0.092)$ & $(0.0946)^{*}$ & $(0.467)$ \\
\hline Nobs & 333 & 334 & 332 & 153 & 153 & 149 \\
\hline
\end{tabular}


Table 12 The result of FE model (2) for key variables of religiosity for combined data

\begin{tabular}{|c|c|c|c|}
\hline \multirow[b]{2}{*}{ Dependent variable } & \multicolumn{3}{|c|}{ Independent variable } \\
\hline & attend & Ident_relig & born \\
\hline \multirow[t]{2}{*}{ P_health } & -0.1005 & -0.1055 & 0.1528 \\
\hline & $(0.0273)^{* *}$ & $(0.0338)^{* *}$ & $(0.0886)+$ \\
\hline Adj Rsq & 0.1205 & 0.1159 & 0.1014 \\
\hline Nobs & 744 & 746 & 486 \\
\hline \multirow[t]{2}{*}{ M_health } & & -0.1196 & 0.0409 \\
\hline & $-0.084(0.0273)^{* *}$ & $(0.0336)^{* *}$ & (0.0912) \\
\hline Adj Rsq & 0.1765 & 0.1765 & 0.1494 \\
\hline Nobs & 744 & 746 & 487 \\
\hline \multirow[t]{2}{*}{ days } & & 0.3063 & -1.0638 \\
\hline & $0.3094(0.1138)^{* *}$ & $(0.141)^{*}$ & $(0.4286)^{*}$ \\
\hline Adj Rsq & 0.0148 & 0.0112 & 0.0068 \\
\hline Nobs & 736 & 738 & 481 \\
\hline
\end{tabular}




\section{Reference}

Bjorner, Jakob, Peter Fayers, and Ellen Idler. 2005. Self-rated health. In Assessing quality of life in clinical trials: Methods and practice, edited by Peter M. Fayers and Ron D. Hays, pp. 309-24. Oxford, NY: Oxford University Press.

Brenner, Philip and Erica Siegl. 2008. Assessing longitudinal relationships between social factors and health. CDE Working Paper No. 2008-11. Madison, WI: University of Wisconsin.

Byrd, R.C. (1988). Positive Therapeutic Effects of Intercessory Prayer in a Coronary Care Unit Population. Southern Medical Journal 81: 826-829.

Ellison, Christopher G. and Jeffrey S. Levin. 1998. The religion-health connection: Evidence, theory and future directions. Health Education \& Behavior 25(6):700-20.

George, Linda K., Christopher G. Ellison, and David B. Larson. 2002. Explaining the relationships between religious involvement and health. Psychological Inquiry 13(3):190-200.

Geronimus, A. T. and S. Korenman (1992). "The Socioeconomic Consequences of Teen Childbearing Reconsidered." Quarterly Journal of Economics 107(4): 1187-1214.

Harris, W.S., Gowda, M., Kolb, J.W., Strychacz, C.P., Vacek, J.L., Jones, P.G., Forker, A., O'Keefe, J.H., and McCallister, B.D. (1999). A Randomized, Controlled Trial of the Effects of Remote, Intercessory Prayer on Outcomes in Patients Admitted to the Coronary Care Unit. Arch Intern Med. 159:2273-2278.

Idler, Ellen and Stanislav Kasl. 1995. Self-ratings of health: Do they also predict change in functional ability? Journal of Gerontology 50B(6):S344-53.

Kelly-Moore, Jessica and Kenneth Ferraro. 2001. Functional limitations and religious service attendance in later life: Barrier and/or benefit mechanism? Journal of Gerontology 56B(6):S36573.

Koenig, Laura B. and George E. Vaillant. 2009. A prospective study of church attendance and health over the lifespan. Health Psychology 28(1):117-24.

Krause, Neal. 2010. Religion and health: Making sense of a disheveled literature. Journal of Religion and Health 50(1):20-35.

Leibovici, L. (2001). Effects of remote, retroactive intercessory prayer on outcomes in patients with bloodstream infection: randomised controlled trial. British Medical Journal, 323, 1450-1451

Levin, Jeffrey and Linda M. Chatters. 2008. Religion, aging and health: Historical perspectives, current trends, and future directions. Journal of Religion, Spirituality and Aging 20(1-2):153-70. 
Levin, Jeffrey S. (1994), Religion and health: Is there an association, is it valid, and is it causal? Social Science \& Medicine, Volume 38, Issue 11, June 1994 , Pages 1475-1482

Levin, Jeffrey S. (1994), Religion and health: Is there an association, is it valid, and is it causal? Social Science \& Medicine, Volume 38, Issue 11, June 1994, Pages 1475-1482

Levin, Jeffrey S. and Vanderpool, Harold Y. (1987), Is frequent religious attendance really conducive to better health?: Toward an epidemiology of religion, Social Science \& Medicine Volume 24, Issue 7, 1987, Pages 589-600

Musick, Marc and Meredith Worthen. 2010. Religion and physical health among US adults. In Religion, families and health, edited by Christopher Ellison and Robert Hummer, pp. 248-72. New Brunswick, NJ: Rutgers University Press.

Myers, David. 2008. Religion and human flourishing. In The science of subjective well-being, edited by Michael Eid and Randy J. Larsen, pp. 323-43. New York: Guilford Press.

Oman, Doug and Carl Thoreson. 2005. Do religion and spirituality influence health? In Handbook on the psychology of religion and spirituality, edited by Raymond F. Paloutzian and Crystal L. Park, pp. 435-59. New York: Guilford Press.

Oman, Doug and Carl Thoreson. 2005. Do religion and spirituality influence health? In Handbook on the psychology of religion and spirituality, edited by Raymond F. Paloutzian and Crystal L. Park, pp. 435-59. New York: Guilford Press.

Powell, Lynda H., Leila Shahabi, and Carl E. Thorenson. 2003. Religion and spirituality: Linkages to physical health. American Psychologist 58(1):36-52.

Ryff, Carol D., Burton H. Singer, and Gayle Dienberg Love. 2004. Positive health: Connecting well-being with biology. Philosophical Transactions of the Royal Society of London 359(1449):1383-94.

Shields, Margot and Shahin Shooshtari. 2001. Determinants of self-perceived health. Health Reports 13(1):35-52.

Stokes, M.E., Davis, C.S., and Koch, G.G. (1995). Categorical Data Analysis using the SAS System. Cary, NC: SAS Institute Inc.

Thoresen, C. E. (1999). Spirituality and health: Is there a relationship? Journal of Health Psychology, 4, 291-300. 